\title{
Hospitalization causes and outcomes in HIV patients in the late antiretroviral era in Colombia
}

\author{
María Fernanda Álvarez Barreneche ${ }^{1 *}$, Carlos Andrés Restrepo Castro 1,2, Alicia Hidrón Botero 1,3,4,

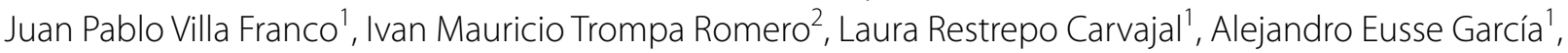 \\ Adriana Ocampo Mesa ${ }^{5}$, Lina María Echeverri Toro ${ }^{5,6}$, Glenys Patricia Porras Fernández de Castro ${ }^{7}$, \\ Jaime Mauricio Ramírez Rivera ${ }^{5,6}$ and Carlos Andrés Agudelo Restrepo 1,5,8
}

\begin{abstract}
Background: Antiretroviral therapy (ART) has modified the natural history of HIV-infection: the incidence of opportunistic infections (Ols) has decreased and mortality associated to HIV has improved dramatically. The reasons for hospitalization have changed; Ols are no longer the most common reason for admission. This study describes the patient population, admission diagnosis and hospital course of HIV patients in Colombia in the ART era.

Methods: Patients admitted with HIV/AIDS at six hospitals in Medellin, Colombia between August 1, 2014 and July 31, 2015 were included. Demographic, laboratory, and clinical data were prospectively collected.

Results: 551 HIV-infected patients were admitted: 76.0\% were male, the median age was 37 (30-49). A new diagnosis of HIV was made in $22.0 \%$ of patients during the index admission. $56.0 \%$ of patients of the entire cohort had been diagnosed with HIV for more than 1 year and 68.9\% were diagnosed in an advanced stage of the disease. More than $50.0 \%$ of patients had CD4 counts less than 200 CD 4 cells/ $\mu \mathrm{L}$ and viral loads greater than 100,000 copies. The main reasons for hospital admissions were Ols, tuberculosis, esophageal candidiasis and Toxoplasma encephalitis. The median hospital stay was 14 days (IQR 8-23). Admission to the intensive care unit (ICU) was required in 10.3\% of patients and $14.3 \%$ were readmitted to the hospital; mortality was $5.4 \%$.

Conclusions: Similar to other countries in the developing world, in Colombia, the leading cause of hospitalization among HIV-infected patients remain opportunistic infections. However, in-hospital mortality was low, similar to those described for high-income countries. Strategies to monitor and optimize the adherence and retention in HIV programs are fundamental to maximize the benefit of ART.
\end{abstract}

Keywords: Acquired immune deficiency syndrome, Human immunodeficiency virus, Hospitalization, Opportunistic infections, Antiretroviral, Adherence

\section{Background}

Life expectancy for patients infected with the human immunodeficiency virus (HIV) has improved significantly in the era of antiretroviral therapy (ART), largely due to the reduction in mortality attributable to diseases

\footnotetext{
*Correspondence: mariafda_12@hotmail.com

1 School of Health Sciences, Universidad Pontificia Bolivariana, Carrera 44

\# 18-56, Antioquia, Medellín, Colombia

Full list of author information is available at the end of the article
}

related to acquired immunodeficiency syndrome (AIDS) [1]. A recent systematic review and meta-analysis has summarized data on causes of hospital admission among children and adults living with HIV globally: AIDSrelated illnesses (including tuberculosis [TB]) and bacterial infections were the second most common cause of adult HIV admissions in all geographical regions and the most common cause of hospital mortality [2]. Studies in high-income countries have shown changes in the main causes of hospitalization and death of HIV patients: 
opportunistic diseases have given way to chronic diseases and neoplasms not associated with AIDS [2-5]. On the other hand, in developing countries, high mortality rates persist despite availability of antiretrovirals; AIDS defining events continue to be reported as the main cause of hospitalization and death [6-10].

Although the change in the epidemiological profile of hospitalized patients with HIV has been widely documented in high-income and in developing countries, litthe is known about the reasons for hospital admission and hospital outcomes in the current era of the HIV epidemic in Colombia [11, 12]. This study describes the clinical characteristics, causes of hospital admission and mortality rates of patients with HIV infection from six high complexity care hospitals in Medellin, Colombia.

\section{Methods}

\section{Study design and patient collection}

Patients diagnosed with HIV, older than 18 years of age and hospitalized for more than $24 \mathrm{~h}$ in any of six reference hospitals in Medellin, Colombia, between August 1, 2014 and July 31, 2015, were included. Patients who were unconscious, pregnant women (who are usually treated in high risk obstetric units in Colombia, not in the infectious disease ward) and patients who did not agree to participate were excluded. The information was prospectively collected using Magpi ${ }^{\circledR}$ software (formerly DataDyne, Washington, WA), and included socio-demographic variables, baseline characteristics at admission, reason for hospital admission and clinical outcomes. Patients that could not be interviewed were excluded from the analysis, but the reason for admission was recorded. The definitions of the variables were based on previous studies and those established by National Institutes of Health [13]. Adherence measurement was given by self-report of the patient: the patient taking more than $95 \%$ of total doses in the last month was defined as adherent according with Simoni et al. [14]. Hospital readmission was defined as a new (different) hospitalization for the same cause during the year of the study. Laboratory data and clinical outcomes were extracted from the patient's medical chart.

\section{Ethics statement}

The study was approved by the ethics committee of each of the participating hospitals. All study participants provided a written informed consent for collecting information; the patient's identity was protected, individual records were coded and accessed only by research staff. None of the enrolled participants were below 18 years of age. A post hoc authorization was given to review the clinical records of all HIV patients hospitalized at participating hospitals during the study period in order to identify patients lost due to care in services other than infectious diseases.

\section{Statistical analysis}

Data were exported to SPSS ${ }^{\circledR}$ version 17 (IBM, Armonk, NY) to perform analyses using frequency distribution measures for qualitative variables and measures of central tendency, dispersion and position for quantitative variables. Manual review of medical records was performed to resolve discrepancies found in the database.

\section{Results}

901 HIV-positive patients were hospitalized during the year of the study in participating institutions, representing $0.79 \%$ of 114.505 admissions. Of those, 551 patients were included. One hundred twenty-six (14\%) patients were excluded and 224 (24.9\%) patients were missed, mainly because they were cared for by services other than infectious diseases (Fig. 1).

The median age was 37 years (IQR 30-49). Patients mostly belonged to a low socioeconomic class $(n=372$, $67.5 \%$ ) with a basic education level (only elementary and/ or high school) in $70.8 \%$ (390 patients). HIV diagnosis was made in advanced stage disease $(<200$ CD4 cells/ $\mu \mathrm{L}$ and/or AIDS defining entities) in 68.9\% (380) of the patients. More than $50.0 \%$ of patients had CD4 counts less than $200 \mathrm{CD} 4$ cells $/ \mu \mathrm{L}$ and viral loads greater than 100,000 copies at admission. Diagnosis of HIV was made during the index admission in $22 \%$ (121) of patients and their median CD4 count was 59 cells/ $\mu \mathrm{L}$ (interquartile range [IQR] 27-149.5). Of the 430 patients with a previous HIV diagnosis, $42 \%$ (181 patients) had already had an opportunistic infection, with tuberculosis being the most common one. In this group, ART had been prescribed to $85.1 \%$ (366/430), but only $63.4 \%$ (273/430) were receiving it on admission, and only 199 patients (54.1\%) reported being adherent to ART. The main reasons for non-adherence were drug dependence, social or occupational instability, psychiatric disorders and lack of family support. Multiple antiretroviral regimens have been received by $48 \%(175 / 366)$ of patients; the average number of previous regimens was $1.5(\mathrm{SD} \pm 0.82)$.

Baseline characteristics were similar for all patients compared to the subsets of patients with a previous HIV diagnosis and a prior AIDS-defining illness, except the median CD4 count was lower and the proportion of patients without antiretroviral therapy was greater in the AIDS-defining illness group (Table 1).

The main reason for hospitalization was an AIDSdefining illness in 54.6\% (301/551) of patients, and tuberculosis was the most frequent OI in this group (42.5\%, $128 / 301)$. The second most frequent reason for admission were non HIV-related affections with bacterial 


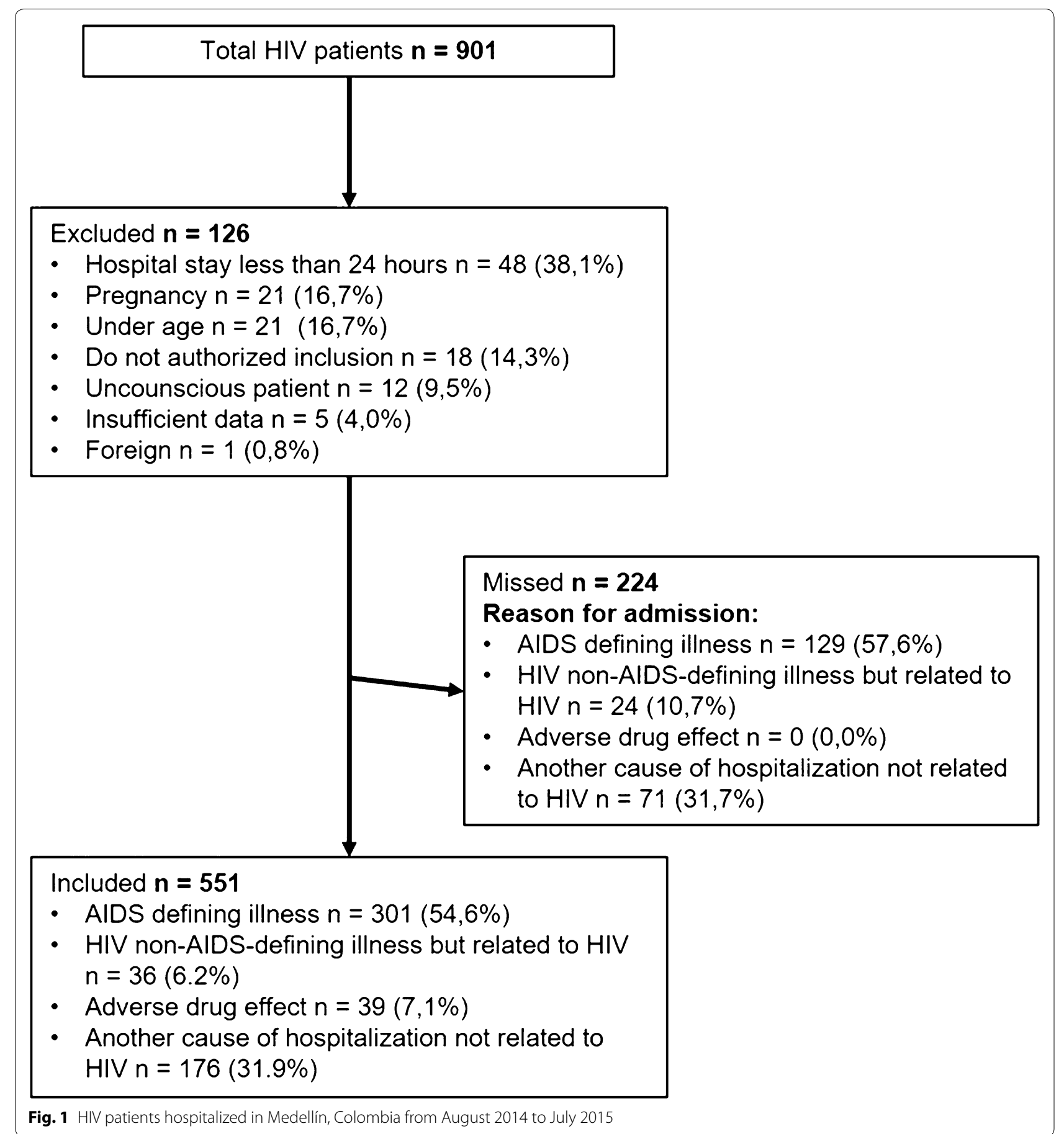

infections predominating (11.0\%, 62 of 551 hospitalizations) (Table 2).

Admission to the ICU was required in 57 patients (10.3\%); of these, 33.3\% (19) had tuberculosis. Median hospital stay was 14 days (IQR 8-23) and 14.3\% (79) of patients required re-admission to the hospital. Adverse events to medications received during the hospital stay were reported for $9.6 \%(\mathrm{n}=57)$ of the patients. Nosocomial infections were reported for 27 patients (4.9\%).

Global mortality was $5.4 \%$ (30/551 patients). Of the patients who died, $70 \%(\mathrm{n}=21)$ had a previous diagnosis of HIV, $52.4 \%(\mathrm{n}=11)$ were receiving ART, and $38.1 \%$ $(\mathrm{n}=8)$ were being followed-up in an HIV program. $96.6 \%(n=28)$ of the patients that died had less than 50 
Table 1 Baseline characteristics for 551 patients with HIV infection admitted to medical ward

\begin{tabular}{|c|c|c|c|}
\hline Patient characteristics & $\begin{array}{l}\text { All patients, } n=551 \\
(100 \%)\end{array}$ & $\begin{array}{l}\text { Previous HIV diagnosis, } n=430 \\
(78 \%)\end{array}$ & $\begin{array}{l}\text { AIDS-defining illness, } \\
n=301 \\
(54.6 \%)\end{array}$ \\
\hline Age, median (IQR) & $37(30-49)$ & $36(30-48)$ & $37(30-50)$ \\
\hline Male & $418(76)$ & $321(74.6)$ & $231(76.7)$ \\
\hline Low income & $372(67.5)$ & $289(67.2)$ & $225(74.7)$ \\
\hline Lower educational attainment & $390(70.8)$ & $188(43.7)$ & $154(51.1)$ \\
\hline New HIV diagnosis & $121(22)$ & - & $88(29.2)$ \\
\hline \multicolumn{4}{|l|}{ ART status } \\
\hline Receiving ART prior to admission & $273(49.5)$ & $273(63.4)$ & $131(43.5)$ \\
\hline Not on ART & $278(50.4)$ & $64(14.9)$ & $111(36.8)$ \\
\hline Abandonment of ART & - & $93(21.6)$ & $59(19.6)$ \\
\hline Adherence to $\mathrm{ART}^{\mathrm{a}}$ & - & 199/366 (54.4) & $83 / 190(43.6)$ \\
\hline Attending HIV program & - & $258(60.0)$ & $86(28.5)$ \\
\hline Attending HIV program and receiving ART & - & $226 / 258(87.6)$ & $72(23.9)$ \\
\hline $\begin{array}{l}\text { CD4 cell count, cells/ } \mu \mathrm{l} \\
\text { Median (IQR) }\end{array}$ & $98(36.2-98)$ & $117(41-310)$ & $59(24-131)$ \\
\hline $\begin{array}{l}\text { HIV viral load, copies/mL } \\
\text { Median (IQR) }\end{array}$ & $100.278(1.505-384.250)$ & $36.381(77-216.441)$ & $\begin{array}{l}179.000(26.597- \\
622.022)\end{array}$ \\
\hline Anemia $^{b}$ & $104(18.9)$ & $90(20.9)$ & $76(25.2)$ \\
\hline Past history of TB & $88(20.4)$ & $88(20.4)$ & 55 (18.2) \\
\hline
\end{tabular}

adherence to ART is calculated with patients who had abandoned ART or were receiving ART prior to admission

${ }^{b}$ Anemia was defined using WHO criteria (hemoglobin $<11.0 \mathrm{~g} / \mathrm{dL}$ for both males and females)

CD4 cells $/ \mu \mathrm{L}, 80 \%(\mathrm{n}=24)$ had been admitted for an AIDS-defining illness, and $36.6 \%$ (11 patients) had two or more OIs (Table 3).

\section{Discussion}

This study describes the clinical characteristics, main causes of hospitalization and mortality rates in adult patients with HIV in a developing country. Contrary to what has been reported in high-income countries where cardiovascular, hepatic or neoplastic etiologies not associated with AIDS are the main causes of hospitalization [15-18], we found OIs to be the main reason for admission and mortality. Of the 30 patients who died, $80 \%$ (24 patients) died due to the opportunistic infection that caused the admission.

In low and middle-income countries the majority of admissions are still due to AIDS-defining events; a significant proportion of patients get diagnosed with HIV during this index admission or die with a recent diagnosis [6, 19]. Differences in opportunities to have access to programs, provision of medication and a timely diagnosis have been shown to influence the outcome of patients [20]. In our study $78 \%$ of hospitalized patients had a known diagnosis of HIV, 60\% were getting followup in an HIV program and close to $60 \%$ were on ART. However, $57 \%$ (155) of patients on ART did not have adequate immunovirologic control. Our findings parallel national surveillance data in reference to HIV epidemiology [21]. In 2016, of 73,465 HIV-patients, 91.5\% had access to ART, and, nonetheless, only $57.5 \%$ had accomplished virologic suppression [21]. The reasons for this gap between access to care and immunovirologic control were not directly assessed by our study. Most of our patients had socio-economic conditions that could favor non-adherence to ART [22, 23]. Our findings, in alignment with national data, suggest public health measures focusing on strategies to improve adherence and retention in HIV programs to maximize the benefit of antiretroviral treatment.

Studies from other developing countries report high mortality rates in patients hospitalized with HIV compared to those of industrialized countries (up to $38 \%$ vs. 2.6\%). Mortality is associated to advanced disease stages, severity of immunologic compromise (low CD4 count), presence of opportunistic infections, and lack of resources for care $[6,15]$. Although Colombia is considered a low-middle income country, we found comparable hospital mortality rates (5\%) to those of industrialized countries $[15,16,18]$ despite opportunistic infections as the primary reason for admission and advanced disease stage. This discrepancy between high frequency of opportunistic infections and low mortality is unexpected and could possibly reflect gaps in the overall quality of acute versus long-term, ambulatory care. Whether the 
Table 2 Causes of hospitalization in HIV patients in Medellín, Colombia from August 2014 to July 2015 ( $N=551)$

\begin{tabular}{|c|c|}
\hline Variable & n (\%) \\
\hline AIDS defining illness ${ }^{a}$ & $301(54.6)$ \\
\hline Tuberculosis & $128(23.3)$ \\
\hline Extrapulmonary tuberculosis & $84(15.2)$ \\
\hline Pulmonary tuberculosis & $44(8.0)$ \\
\hline Esophageal candidiasis & $56(10.1)$ \\
\hline Toxoplasma encephalitis & $43(7.8)$ \\
\hline Disseminated histoplasmosis & $39(7.1)$ \\
\hline CMV infection & $36(6.5)$ \\
\hline Extrapulmonary cryptococcosis & $32(5.8)$ \\
\hline Pneumonia by P.jiroveci & $32(5.8)$ \\
\hline Lymphoma $^{\mathrm{b}}$ & $27(4.9)$ \\
\hline Kaposi's sarcoma & $11(2.0)$ \\
\hline Herpes simplex $>1$ month & $10(1.8)$ \\
\hline Cryptosporidiosis $>1$ month & $10(1.8)$ \\
\hline HIV Encephalopathy & $8(1.4)$ \\
\hline Wasting syndrome & $7(1.3)$ \\
\hline MAC & $4(0.7)$ \\
\hline Recurrent salmonellosis & $2(0.3)$ \\
\hline Adverse drug effect & $39(7.1)$ \\
\hline Non-AIDS-defining illness but related to HIV & $35(6.2)$ \\
\hline Another cause of hospitalization not related to HIV & $176(31.9)$ \\
\hline Bacterial infection & $61(11.0)$ \\
\hline Others $^{c}$ & $115(20.9)$ \\
\hline \multicolumn{2}{|c|}{$\begin{array}{l}\text { The total percentage exceeds } 100 \% \text { because some patients had }>1 \text { defining } \\
\text { illness }\end{array}$} \\
\hline \multicolumn{2}{|c|}{$\begin{array}{l}\text { b Burkitt lymphoma, primary central nervous system lymphoma, immunoblastic } \\
\text { lymphoma }\end{array}$} \\
\hline $\begin{array}{l}\text { c Other: gastrointestinal, neurological, hematological a } \\
\text { viral infection, pneumopathy, reactive lymphadenopat }\end{array}$ & terations, \\
\hline
\end{tabular}

low mortality rate observed is due to the quality of care provided in high-complexity hospitals with highly trained staff and medical resources to care for these patients, remains to be proved. However, previous studies suggest that increased physician experience in caring for patients with AIDS improves survival [24-26].

Strengths of the study include that it is a large, multicenter study with prospective design. Patients that were not included were analyzed retrospectively, finding similar causes of admission to those reported for the entire cohort (Fig. 1). Among the weaknesses, researchers did not have access to outpatient medical records, so information about HIV history was obtained from patient interviews, which could be associated with memory bias. Because of the prospective nature of the study and the requirement for informed consent, patients with $\mathrm{CNS}$ involvement who were unable to consent and who lacked a family member capable to do so were excluded. We recognize that this behavior might have generated some
Table 3 Main findings of HIV patients in Medellín, Colombia from August 2014 to July 2015

\begin{tabular}{|c|c|c|}
\hline Variable & $\begin{array}{l}\text { Patients who } \\
\text { died }(n=30) \\
n(\%)\end{array}$ & $\begin{array}{l}\text { Patients who sur- } \\
\text { vived }(n=521) \\
n(\%)\end{array}$ \\
\hline Age & 41.5 & 39.3 \\
\hline Male & $25 / 30(83.3)$ & $393 / 521(75.4)$ \\
\hline $\begin{array}{l}\text { Diagnosis during the index } \\
\text { admission }\end{array}$ & $9 / 30(30.0)$ & $112 / 521(21.5)$ \\
\hline Previous HIV diagnosis ${ }^{\mathrm{a}}$ & $21 / 30(70.0)$ & $409 / 521(78.5)$ \\
\hline Diagnosis 1-12 months & $6 / 30(20.0)$ & $117 / 521(22.5)$ \\
\hline Diagnosis > 12 months & $15 / 30(50.0)$ & $292 / 521(56.0)$ \\
\hline $\begin{array}{l}\text { On antiretroviral therapy at } \\
\text { admission }^{\text {b }}\end{array}$ & $11 / 21(52.4)$ & $262 / 409(64.2)$ \\
\hline Adherence $^{c}$ & $5 / 18(27.7)$ & 194/354 (54.8) \\
\hline $\begin{array}{l}\text { CD4 T-cells count }<200 \text { cells/ } \\
\mathrm{mL}^{\mathrm{d}}\end{array}$ & 28/29 (96.6) & $352 / 521(67.4)$ \\
\hline $\begin{array}{l}\text { AIDS-defining illness on admis- } \\
\text { sion }\end{array}$ & $24 / 30(80.0)$ & $277 / 521(53.2)$ \\
\hline $\begin{array}{l}\text { Patients with newly diagnosed } \\
\text { TB }\end{array}$ & $7 / 30(23.3)$ & $121 / 521(23.2)$ \\
\hline AIDS defining illness no TB & $17 / 30(56.6)$ & 156/521 (29.9) \\
\hline Two or more Ols & $11 / 30(36.6)$ & 96/521 (18.4) \\
\hline $\begin{array}{l}\text { Non-AIDS-defining illness but } \\
\text { related to HIV }\end{array}$ & $2 / 30(6.6)$ & $33 / 521(6.3)$ \\
\hline \multirow{2}{*}{\multicolumn{3}{|c|}{$\mathrm{a} \geq 1$ month previous to hospitalization }} \\
\hline & fore admission & \\
\hline & & \\
\hline
\end{tabular}

selection bias in the study. Additionally, patients were cared for in reference hospitals in Medellín, institutions with highly specialized staff and advanced technological resources. This is not the case for many health institutions in Colombia nor perhaps for health institutions in other developing countries. Our data may not be generalized to smaller cities in developing countries with differ to what happens in other Colombian cities lower complexity care hospitals.

\section{Conclusion}

Opportunistic infections continue to be de the leading cause of hospitalization in adult HIV patients in Colombia. The gap between access to care and treatment and treatment goal achievement reflect possible programmatic limitations. Despite this, mortality rates observed were low, similar to those described for high-income countries. Our findings suggest focusing on measures to improve retention in care, ensure adherence and improve the opportunity for diagnosis, could have a long-term positive impact on the incidence of opportunistic infections and hospital admissions. 


\section{Abbreviations}

AIDS: acquired immunodeficiency syndrome; ART: antiretroviral therapy; HIV: human immunodeficiency virus; ICU: intensive care unit; MAC: Mycobacterium avium complex; Ol: opportunistic infections.

\section{Authors' contributions}

MFA, CAR and CAA proposed the idea; MFA, CAA, CAR, AlH, JPV and IMT together designed the study. All authors contributed in data collection, analysis and manuscript preparation. MFA, CAR, AlH, CAA drafted the manuscript. All authors read and approved the final manuscript.

\section{Author details}

${ }^{1}$ School of Health Sciences, Universidad Pontificia Bolivariana, Carrera 44 \# 18-56, Antioquia, Medellín, Colombia. ${ }^{2}$ Division of Infectious Diseases, Department of Internal Medicine, IPS Universitaria Clínica León XIII, Antioquia, Medellín, Colombia. ${ }^{3}$ Division of Infectious Diseases, Department of Internal Medicine, Hospital Pablo Tobón Uribe, Antioquia, Medellín, Colombia. ${ }^{4}$ Division of Infectious Diseases, Department of Internal Medicine, Emory University School of Medicine, Atlanta, GA, USA. ${ }^{5}$ Division of Infectious Diseases, Department of Internal Medicine, Centros Especializados San Vicente Fundación, Antioquia, Rionegro, Colombia. ${ }^{6}$ Division of Infectious Diseases, Department of Internal Medicine, Hospital Universitario, San Vicente Fundación, Antioquia, Medellín, Colombia. ${ }^{7}$ Department of Internal Medicine, Hospital General de Medellín, Antioquia, Medellín, Colombia. ${ }^{8}$ Division of Infectious Diseases, Department of Internal Medicine, Clínica Universitaria Bolivariana, Antioquia, Medellín, Colombia.

\section{Acknowledgements}

We thank Clínica Bolivariana, IPS Universitaria Clínica León XXIII, Hospital Pablo Tobón Uribe, Hospital San Vicente Fundación, Hospital General de Medellín, for allowing us to carry out the study in each of the institutions.

\section{Competing interests}

The authors declare that they have no competing interests.

\section{Availability of data and materials}

The dataset can be available from the corresponding author at any time.

\section{Consent for publication}

Not applicable.

\section{Ethics approval and consent to participate}

The study was approved by the ethics committee of each of the participating hospitals. All study participants provided a written informed consent for collecting information the patient's identity was protected, individual records were coded and accessed only by research staff. None of the enrolled participants were below 18 years of age. A post hoc authorization was given to review the clinical records of all HIV patients hospitalized at participating hospitals during the study period in order to identify patients lost due to care in services other than infectious diseases.

\section{Publisher's Note}

Springer Nature remains neutral with regard to jurisdictional claims in published maps and institutional affiliations.

Received: 29 August 2017 Accepted: 9 November 2017

Published online: 13 November 2017

\section{References}

1. Mocroft A, Ledergerber B, Katlama C, Kirk O, Reiss P, d'Arminio Monforte $A$, et al. Decline in the AIDS and death rates in the EuroSIDA study: an observational study. Lancet. 2003. https://doi.org/10.1016/ S0140-6736(03)13802-0.

2. Ford N, Shubber Z, Meintjes G, Grinsztejn B, Eholie S, Mills EJ, et al. Causes of hospital admission among people living with HIV worldwide: a systematic review and meta-analysis. Lancet HIV. 2015. https://doi.org/10.1016/ s2352-3018(15)00137-X.
3. May M, Gompels M, Delpech V, Porter K, Post F, Johnson M, et al. Impact of late diagnosis and treatment on life expectancy in people with HIV-1: UK Collaborative HIV Cohort (UK CHIC) Study. BMJ. 2011. https://doi. org/10.1136/bmj.d6016.

4. Ingle SM, May MT, Gill MJ, Mugavero MJ, Lewden C, Abgrall S, et al. Impact of risk factors for specific causes of death in the first and subsequent years of antiretroviral therapy among HIV-infected patients. Clin Infect Dis. 2014. https://doi.org/10.1093/cid/ciu261.

5. Grinsztejn B, Luz PM, Pacheco AG, Santos DVG, Velasque L, Moreira RI, et al. Changing mortality profile among HIV-infected patients in Rio de Janeiro, Brazil: shifting from AIDS to non-AIDS related conditions in the HAART era. PLoS ONE. 2013. https://doi.org/10.1371/journal. pone.0059768.

6. Lewden C, Drabo YJ, Zannou DM, Maiga MY, Minta DK, Sow PS, et al. Disease patterns and causes of death of hospitalized HIV-positive adults in West Africa: a multicountry survey in the antiretroviral treatment era. J Int AIDS Soc. 2014. https://doi.org/10.7448/IAS.17.1.18797.

7. Martín-Onraet A, Piñeirua-Menéndez A, Perales-Martínez D, Ortega-Pérez R, Barrera-García A, Sierra-Madero J, et al. Mortalidad hospitalaria en pacientes con infección por VIH: a diez años del acceso universal a TARAA en México. Salud Pública México. 2015;57(Suppl):163-70.

8. Sharma S, Kadhiravan T, Banga A, Goyal T, Bhatia I, Saha P. Spectrum of clinical disease in a series of 135 hospitalized HIV-infected patients from North India. BMC Infect Dis. 2004. https://doi. org/10.1186/1471-2334-4-52.

9. Sharifi-Mood B, Alavi-Naini R, Salehi M, Hashemi M, Rakhshani F. Spectrum of clinical disease in a series of hospitalized HIV-infected patients from southeast of Iran. Saudi Med J. 2006;27:1362-6.

10. Meintjes G, Kerkhoff AD, Burton R, Schutz C, Boulle A, Van Wyk G, et al. HIV-related medical admissions to a South African district hospital remain frequent despite effective antiretroviral therapy scale-up. Medicine (Baltimore). 2015. https://doi.org/10.1097/MD.0000000000002269.

11. Montúfar Andrade F, Quiroga A, Builes C, Saldarriaga C, Aguilar C, Mesa $M$, et al. Epidemiology of human immunodeficiency virus infection in inpatients in a teaching hospital of high complexity in Medellin. Colomb Infect. 2016. https://doi.org/10.4067/S0716-10182014000600015.

12. Agudelo-Gonzalez S, Murcia-Sanchez F, Salinas D, Osorio J. Infecciones oportunistas en pacientes con VIH en el hospital universitario de Neiva, Colombia 2007-2012. Infect. 2015;19(2):52-9. https://doi.org/10.1016/j. infect.2014.11.008.

13. Guidelines for prevention and treatment of opportunistic infections in HIV-infected adults and adolescents. https://aidsinfo.nih.gov/contentfiles/lvguidelines/adult_oi.pdf. Accessed 1 Jan 2017.

14. Simoni JM, Kurth AE, Pearson CR, Pantalone DW, Merrill JO, Frick PA Self-report measures of antiretroviral therapy adherence: a review with recommendations for HIV research and clinical management. AIDS Behav. 2006. https://doi.org/10.1007/s10461-006-9078-6.

15. Kim JH, Psevdos G, Gonzalez E, Singh S, Kilayko MC, Sharp V. All-cause mortality in hospitalized HIV-infected patients at an acute tertiary care hospital with a comprehensive outpatient HIV care program in New York City in the era of highly active antiretroviral therapy (HAART). Infection. 2013. https://doi.org/10.1007/s15010-012-0386-7.

16. Weber R, Ruppik M, Rickenbach M, Spoerri A, Furrer H, Battegay $M$, et al. Decreasing mortality and changing patterns of causes of death in the Swiss HIV Cohort Study. HIV Med. 2013. https://doi. org/10.1111/j.1468-1293.2012.01051.x.

17. Corbett EL, Churchyard GJ, Charalambos S, Samb B, Moloi V, Clayton TC et al. Morbidity and mortality in South African gold miners: impact of untreated disease due to human immunodeficiency virus. Clin Infect Dis. 2002. https://doi.org/10.1086/339540.

18. Reekie J, Kowalska JD, Karpov I, Rockstroh J, Karlsson A, Rakhmanova A, et al. Regional differences in AIDS and non-AIDS related mortality in HIVpositive individuals across Europe and Argentina: the EuroSIDA Study. PLoS ONE. 2012. https://doi.org/10.1371/journal.pone.0041673.

19. Fisher M. Late diagnosis of HIV infection: major consequences and missed opportunities. Curr Opin Infect Dis. 2008. https://doi.org/10.1097/ QCO.0b013e3282f2d8fb.

20. Cesar C, Koethe JR, Giganti MJ, Rebeiro P, Althoff KN, Napravnik S, et al. Health outcomes among HIV-positive Latinos initiating antiretroviral therapy in North America versus Central and South America. J Int AIDS Soc. 2016. https://doi.org/10.7448/IAS.19.1.20684. 
21. VIH Cuenta de alto Costo Colombia http://cuentadealtocosto.org/site/ index.php/patologias/9-patologias/34-vih1/?template=cuentadealtocos tocontenido. Accessed 22 Oct 2017.

22. Negash T, Ehlers V. Personal factors influencing patients' adherence to ART in Addis Ababa. Ethiopia. J Assoc Nurses AIDS Care. 2013;24(6):530-8. https://doi.org/10.1016/j.jana.2012.11.004.

23. Hudelson C, Cluver L. Factors associated with adherence to antiretroviral therapy among adolescents living with HIV/AIDS in low- and middleincome countries: a systematic review. AIDS Care. 2015;27(7):805-16. https://doi.org/10.1080/09540121.2015.1011073.

24. Cunningham WE, Tisnado DM, Lui HH, Nakazono TT, Carlisle DM. The effect of hospital experience on mortality among patients hospitalized with acquired immunodeficiency syndrome in California. Am J Med. 1999. https://doi.org/10.1016/S0002-9343(99)00195-3.

25. Kitahata MM, Van Rompaey SE, Dillingham PW, Koepsell TD, Deyo RA, Dodge $W$, et al. Primary care delivery is associated with greater physician experience and improved survival among persons with AIDS. J Gen Intern Med. 2003. https://doi.org/10.1046/j.1525-1497.2003.11049.x19.

26. Kitahata MM, Koepsell TD, Deyo RA, Maxwell CL, Dodge WT, Wagner EH. Physicians' experience with the acquired immunodeficiency syndrome as a factor in patients' survival. N Engl J Med. 1996. https://doi.org/10.1056/ NEJM199603143341106.

\section{Submit your next manuscript to BioMed Central and we will help you at every step:}

- We accept pre-submission inquiries

- Our selector tool helps you to find the most relevant journal

- We provide round the clock customer support

- Convenient online submission

- Thorough peer review

- Inclusion in PubMed and all major indexing services

- Maximum visibility for your research

Submit your manuscript at www.biomedcentral.com/submit
() Biomed Central 